\title{
具有优异热稳定性的磷修饰氧化钛及其对水中污染物的降解
}

\author{
金 辰，邱顺晨，朱月香"，谢有畅 \\ 北京大学化学与分子工程学院, 分子动态与稳态结构国家重点实验室, 北京分子科学国家实验室, 北京 100871
}

\begin{abstract}
摘要: 通过水热法制得磷修饰氧化钛, 它在亚甲基蓝和对氯苯酚的降解以及消除大肠杆菌的实验中都表现出高于纯氧化钛的优 异活性, 甚至优于商品化催化剂 P25. 在捕获剂中降解亚甲基蓝的实验证实羟基自由基是最主要的活性氧物种, 并且磷修饰氧化 钛在光照下拥有较强的产生羟基自由基的能力. 同时, 磷修饰氧化钠具有非常高的热稳定性, 直到 $950^{\circ} \mathrm{C}$ 才会发生从锐铁矿到 金红石的相变,这是因为粒子表面的磷酸根阻止了金红石在界面的成核因而抑制了相变发生. 磷修饰氧化钛的这种优异性质使 得它即使在 $900{ }^{\circ} \mathrm{C}$ 焙烧后也能有效地降解水中污染物.
\end{abstract}

关键词：磷修饰；氧化钛；光催化；热稳定性；抗菌

中图分类号: 0643 文献标识码: A

收稿日期: 2011-02-21. 接受日期: 2011-04-01.

*通讯联系人. 电话: (010)62751703; 传真: (010)62751708; 电子信箱: zhuyx@pku.edu.cn

基金来源：国家自然科学基金 (20973012); 国家重点基础研究发展计划 (973 计划, 2011CB808702).

本文的英文电子版(国际版)由Elsevier出版社在ScienceDirect上出版(http://www.sciencedirect.com/science/journal/18722067).

\section{Phosphorous-Modified $\mathrm{TiO}_{2}$ with Excellent Thermal Stability and Its Application to the Degradation of Pollutants in Water}

\author{
JIN Chen, QIU Shunchen, ZHU Yuexiang ${ }^{*}$, XIE Youchang \\ Beijing National Laboratory for Molecular Science, State Key Laboratory for Structural Chemistry of Unstable and Stable Species, \\ College of Chemistry and Molecular Engineering, Peking University, Beijing 100871, China
}

\begin{abstract}
The phosphorous-modified $\mathrm{TiO}_{2}\left(\mathrm{P}-\mathrm{TiO}_{2}\right)$ was synthesized by a hydrothermal method. The as-prepared $\mathrm{P}-\mathrm{TiO} \mathrm{O}_{2}$ was evaluated for the degradation of methylene blue, the dechlorination of 4-chlorophenol, and the inactivation of Escherichia coli. In all these experiments, $\mathrm{P}-\mathrm{TiO}_{2}$ shows superior activity compared with pure $\mathrm{TiO}_{2}$ and even better activity than the commercially available $\mathrm{P} 25$ in most cases. By carrying out methylene blue degradation in the presence of different scavengers, $\bullet \mathrm{OH}$ radicals were found to be the dominant reactive oxidizing species. The excellent performance of $\mathrm{P}^{-\mathrm{TiO}_{2}}$ was correlated with its pronounced ability to generate $\cdot \mathrm{OH}$ radicals under illumination. We also found that $\mathrm{P}_{-} \mathrm{TiO}_{2}$ is extraordinarily stable against annealing. Its transformation from anatase to rutile does not occur until calcination as high as $950{ }^{\circ} \mathrm{C}$. This phase transformation is retarded since the phosphate species on the surface of the particles acts as a barrier to grain boundary nucleation. This peculiar feature of $\mathrm{P}_{-} \mathrm{TiO}_{2}$ gives it reliable performance during water decontamination even after calcination at $900{ }^{\circ} \mathrm{C}$ since it retains a $100 \%$ anatase phase at this stage.
\end{abstract}

Key words: phosphorous modification; titanium dioxide; photocatalysis; thermal stability; antibacterial

Received 21 February 2011. Accepted 1 April 2011.

*Corresponding author.Tel: +86-10-62751703; Fax:+86-10-62751708; E-mail: zhuyx@pku.edu.cn

This work was supported by the National Natural Science Foundation of China (20973012) and the National Basic Research Program of China (973 Program, 2011CB808702).

English edition available online at Elsevier ScienceDirect (http://www.sciencedirect.com/science/journal/18722067).

The photocatalytic degradation of organic pollutants and the inactivation of microorganisms with titanium dioxide as a photocatalyst is of current interest [1,2]. As an advanced oxidation process [3] it provides an environmentally benign and economically feasible way to purify and decontaminate wastewater. Many studies have been undertaken that were 
concerned with the mechanism of this photocatalytic oxidation [4-6]. When $\mathrm{TiO}_{2}$ is irradiated by light with a higher energy than its bandgap electrons $\left(\mathrm{e}^{-}\right)$are excited to the conduction band, which leads to the generation of positive holes $\left(\mathrm{h}^{+}\right)$in the valance band. These $\mathrm{h}^{+}$react with adsorbed water and hydroxyl groups to give strong oxidizing species such as $\bullet \mathrm{OH}$ radicals and $\mathrm{O}^{-} \cdot$, which are able to degrade a wide range of water contaminants such as dyes, pesticides, bacteria, and viruses.

Rutile, anatase, and brookite are the common polymorphs of titania. Generally, the metastable anatase shows higher photoactivity than the others but it transforms to rutile upon heating at $600-700{ }^{\circ} \mathrm{C}$ and it then suffers a loss of photoactivity [7-10]. The fabrication of a hygienic coating on ceramics requires annealing at temperatures above 900 ${ }^{\circ} \mathrm{C}$. It has been found that the antibacterial performance is greatly weakened by the presence of rutile [11]. Much effort has been devoted to the enhancement of the thermal stability of anatase [12-15]. Loading titania onto a stable support such as $\mathrm{SiO}_{2}$ is an effective method to meet this challenge [12], however, the presence of large amounts of the inactive support will impair the photocatalytic activity. Nanocrystalline $\mathrm{TiO}_{2}$ synthesized with ionic liquid and surfactant molecules shows remarkable stability against calcination [14] but this method is expensive and inconvenient. The supercritical method is also very promising for the enhancement of the thermal stability of $\mathrm{TiO}_{2}$ [16-18]. Lu et al. [16] prepared $\mathrm{Fe}-\mathrm{TiO}_{2}$ by supercritical ethanol drying, which stabilized anatase up to $800{ }^{\circ} \mathrm{C}$.

Non-metal doping such as N, S, and F doping is commonly used to increase the photocatalytic activity of $\mathrm{TiO}_{2}$ [19-21]. Recent results have shown that phosphorous-doping or phosphate-modification can effectively increase the photocatalytic activity of $\mathrm{TiO}_{2}$ and several authors have also addressed its excellent thermal stability [22-25]. Korosi et al. [24] found that phosphate-modified titanium remained in the anatase phase at $700{ }^{\circ} \mathrm{C}$. Li et al. [25] reported that the $\mathrm{P}$ species hindered particle growth in anatase and increases the temperature of anatase-to-rutile phase transformation. We have also optimized the phosphorous effect to enhance the thermal stability of titania [26]. In this work, we prepared phosphorous-modified $\mathrm{TiO}_{2}$ by a simple hydrothermal method. It retains the anatase phase even after calcination at $950{ }^{\circ} \mathrm{C}$ and it also retains a high surface area. The $\mathrm{TiO}_{2}$ phase transition was inhibited by the presence of P-species on its surface. A variety of contaminants can be effectively eliminated on $\mathrm{P}_{-}-\mathrm{TiO}_{2}$ and the reactive oxidizing species involved is characterized in this study.

\section{Experimental}

\subsection{Catalyst preparation}

To synthesize phosphorous-modified $\mathrm{TiO}_{2}, 10.2 \mathrm{~g}$ tetrabutyl titanate was dissolved in $50 \mathrm{ml}$ ethanol, and then this solution was added dropwise to $20 \mathrm{ml}$ phosphorous acid solution under vigorous stirring. The $\mathrm{P} / \mathrm{TiO}_{2}$ molar ratio in the resulting suspensions was 0.02, 0.04, and 0.08 , respectively. After being stirred for $2 \mathrm{~h}$, the mixture was transferred to a $100 \mathrm{ml}$ Teflon-lined stainless steel autoclave, followed by a hydrothermal treatment at $260{ }^{\circ} \mathrm{C}$ for $24 \mathrm{~h}$. After the reaction, the powder sample was filtered, rinsed with ethanol and de-ionized water, and dried in oven at $110^{\circ} \mathrm{C}$ for $12 \mathrm{~h}$. The sample was denoted as $\mathrm{P} x$, where $x$ represents the $\mathrm{P} / \mathrm{Ti}$ molar ratio percentage. Subsequently, the powder was calcined at required temperatures for $3 \mathrm{~h}$ and labeled $\mathrm{P} x-T$, where $T$ represents the calcination temperature. Pure $\mathrm{TiO}_{2}$ without phosphor was prepared by the same procedure except that tetrabutyl titanate was hydrolyzed in pure water.

\subsection{Characterization techniques}

$\mathrm{X}$-ray diffraction (XRD) patterns were acquired on a Rigaku D/MAX-200 diffractometer with Ni-filtered $\mathrm{Cu} K_{\alpha}$ radiation at $40 \mathrm{kV}$ and $100 \mathrm{~mA}$. X-ray photoelectron (XPS) spectra were obtained on a Kratos Axis Ultra System with monochromatic Al $K_{\alpha}$ X-rays $(1486.6 \mathrm{eV})$. The surface area was determined using a Micromeritics ASAP 2010.

The terephthalic acid photoluminescence probing technique (TAPL) was used to detect hydroxyl radicals $(\bullet \mathrm{OH})$ as discussed in Ref. [27]. The catalyst powder (20 $\mathrm{mg}$ ) was suspended in $80 \mathrm{ml}$ of aqueous solution containing $0.01 \mathrm{~mol} / \mathrm{L} \mathrm{NaOH}$ and $3.0 \mathrm{mmol} / \mathrm{L}$ terephthalic acid. Before exposure to UV light irradiation, the suspension was stirred in the dark for $30 \mathrm{~min}$. Then, $5.0 \mathrm{ml}$ of solution was removed every 30 min and $\mathrm{TiO}_{2}$ was separated from the solution using the centrifugation method. The remaining clear liquid was used for fluorescence spectroscopy measurements with a Hitachi F4500 spectrometer.

\subsection{Photocatalytic activity test}

Test A: methylene blue ( $\mathrm{MB}, \mathrm{C}_{16} \mathrm{H}_{18} \mathrm{~N}_{3} \mathrm{~S}$ ) degradation. The photocatalytic decomposition of $\mathrm{MB}$ was performed under UV irradiation. UV illumination was provided by a 6 W medium-pressure mercury lamp with a main emission peak at $254 \mathrm{~nm}$. The catalyst powder $(50.0 \mathrm{mg})$ was dispersed in $200 \mathrm{ml}$ aqueous MB $\left(1.2 \times 10^{-5} \mathrm{~mol} / \mathrm{L}\right)$. The photocatalytic activity of the catalysts was determined after magnetically stirring the suspension for $1 \mathrm{~h}$ in the dark to achieve an adsorption-desorption equilibrium. At given time intervals, $4 \mathrm{ml}$ of the suspension was removed and 
immediately centrifuged, and the light absorption of the clear solution was measured at $665 \mathrm{~nm}$ by UV-vis spectroscopy.

Test B: 4-chlorophenol (4CP) dechlorination. The same light source mentioned above was used for $4 \mathrm{CP}$ dechlorination. The catalyst powder $(50.0 \mathrm{mg})$ was dispersed in a $200 \mathrm{ml} 4 \mathrm{CP}$ solution $\left(2.5 \times 10^{-4} \mathrm{~mol} / \mathrm{L}\right)$. At given time intervals, aliquots of the suspension were removed and subjected to filtration through a $0.22 \mu \mathrm{m}$ syringe filter (Satorius PES) to remove the catalyst powder. The concentration of 4CP was determined by HPLC (Agilent 1200 series) using a C18 column. A mixture of acetonitrile and deionized water $(50 \%, v / v)$ was used as the mobile phase.

Test C: bacteria inactivation. Escherichia coli MC1061 (E. coli, purchased from The Institute of Microbiology, Chinese Academy of Sciences) was used as a model bacterium for this evaluation. In order to prepare stock cultures stored at $-80{ }^{\circ} \mathrm{C}$, equal amounts of culture and freezing mixture added together and were incubated in LB nutrient broth at $37{ }^{\circ} \mathrm{C}$ for $30-60 \mathrm{~min}$. The samples were dispensed into $1.5 \mathrm{ml}$ sterile plastic screw capped tubes, and frozen. The stock solution $(400 \mu \mathrm{l})$ was inoculated into 50 $\mathrm{ml} \mathrm{LB}$ nutrient broth and grown at $37{ }^{\circ} \mathrm{C}$ for $5 \mathrm{~h}$ under constant agitation. Then the suspension was centrifuged at $3000 \mathrm{rpm}$ for $8 \mathrm{~min}$. The obtained pellet was washed with saline for two times and redispersed into saline water. Cell suspension was adjusted to $\mathrm{OD}_{600}=0.6$ and diluted ten times by saline to form the test suspension (corresponding to $\left.5 \times 10^{7}-1 \times 10^{8} \mathrm{CFU} / \mathrm{ml}\right)$. The catalyst $(40 \mathrm{mg}$ ) was dispersed in a $80 \mathrm{ml} \mathrm{E}$. coli suspension with an initial concentration of approximately $1 \times 10^{8}$ colony forming units per milliliter (CFU/ml). UV illumination was provided by a $100 \mathrm{~W}$ high pressure mercury lamp with a main emission peak at $365 \mathrm{~nm}$. A $360 \mathrm{~nm}$ cut-off filter was used to remove irradiation below $360 \mathrm{~nm}$. At each time interval, aliquots of the $E$. coli suspension were removed and serial dilutions in saline solution were prepared if necessary. To determine the cell viability, $200 \mu$ of the $E$. coli suspension were spread onto LB agar plates. All the plates were incubated at $37^{\circ} \mathrm{C}$ for $16 \mathrm{~h}$ before enumeration.

\section{Results and discussion}

\subsection{State of phosphorous in $\mathrm{P}-\mathrm{TiO}_{2}$}

In an earlier study by our group [28], we characterized and discussed the state of phosphorous in $\mathrm{P}_{-} \mathrm{TiO}_{2}$. Most phosphorous was present as $\mathrm{PO}_{4}{ }^{3-}$, and this was bound to the surface of the $\mathrm{TiO}_{2}$ nanoparticles. Some $\mathrm{P}$ was doped into the bulk of $\mathrm{TiO}_{2}$ leading to the formation of a Ti-O-P bond. This is shown by the diffuse-reflection spectrum
(DRS) of $\mathrm{P}-\mathrm{TiO}_{2}$. Compared with pure $\mathrm{TiO}_{2}$ the absorption edge of $\mathrm{P}_{-} \mathrm{TiO}_{2}$ shows a trivial red shift of several nanometers. Additionally, XPS evidence confirms the presence of a Ti-O-P bond. The Ti $2 p_{3 / 2}$ binding energy moves from $458.4 \mathrm{eV}$ in pure $\mathrm{TiO}_{2}$ to $458.9 \mathrm{eV}$ in $\mathrm{P} 8$ since $\mathrm{P}^{5+}$ is more electronegative than $\mathrm{Ti}^{4+}$. For more details please see Ref. [28].

\subsection{Phase transformation behavior of $\mathrm{P}_{-}-\mathrm{TiO}_{2}$ and pure $\mathrm{TiO}_{2}$}

The evolution of the crystallographic structure is shown in Fig. 1. P2 and the pure $\mathrm{TiO}_{2}$ synthesized by hydrothermal treatment are both in the anatase phase. The rutile diffraction peaks emerged after the pure $\mathrm{TiO}_{2}$ was calcined at $650{ }^{\circ} \mathrm{C}$. The rutile content gradually increases with the calcination temperature and the pure $\mathrm{TiO}_{2}$ converts to rutile completely at $800{ }^{\circ} \mathrm{C}$. By comparison, the phase transformation in $\mathrm{P} 2$ takes place at $950{ }^{\circ} \mathrm{C}$. The crystal sizes and phase content of all the samples are summarized in Table 1 . The rutile content in P4-950 is significantly lower than that in P2-950. Additionally, the phase transformation is further delayed to $1000{ }^{\circ} \mathrm{C}$ for $\mathrm{P} 8$. All these results indicate that the increased phosphorous content is likely to retard the formation of rutile.

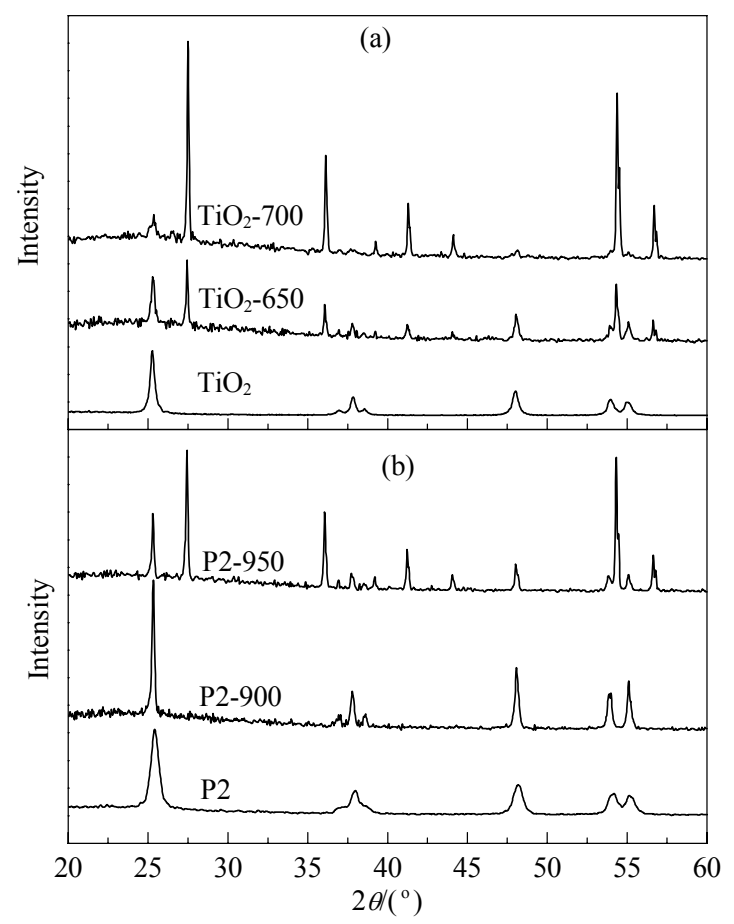

Fig. 1. XRD patterns of pure $\mathrm{TiO}_{2}$ (a) and $\mathrm{P} 2$ (b) before and after calcination.

The transformation temperature of $\mathrm{P}-\mathrm{TiO}_{2}$ and pure $\mathrm{TiO}_{2}$ is different and the transformation process is different as well. Upon calcination, the particle size of pure $\mathrm{TiO}_{2}$ rapidly 
Table 1 Crystal sizes and phase content of pure $\mathrm{TiO}_{2}$ and $\mathrm{P}_{-}-\mathrm{TiO}_{2}$ before and after calcination

\begin{tabular}{lccccc}
\hline \multirow{2}{*}{ Sample } & \multicolumn{2}{c}{ Crystal size $(\mathrm{nm})$} & & \multicolumn{2}{c}{ Phase content ${ }^{\mathrm{b}}(\%)$} \\
\cline { 2 - 3 } \cline { 5 - 6 } & Anatase & Rutile & & Anatase & Rutile \\
\hline $\mathrm{TiO}_{2}$ & 19.3 & - & & 100 & - \\
$\mathrm{TiO}_{2}-650$ & 28.6 & 92.8 & 58.6 & 41.4 \\
$\mathrm{TiO}_{2}-700$ & 27.7 & 87.5 & 12.9 & 87.1 \\
$\mathrm{TiO}_{2}-800$ & - & $>100$ & & - & 100 \\
$\mathrm{P} 2$ & 14.5 & - & 100 & - \\
$\mathrm{P} 2-700$ & 19.6 & - & 100 & - \\
$\mathrm{P} 2-800$ & 25.0 & - & 100 & - \\
$\mathrm{P} 2-900$ & 53.1 & - & 100 & - \\
P2-950 & 63.5 & 78.5 & 32.6 & 67.4 \\
P4-900 & 53.8 & - & 100 & - \\
P4-950 & 62.2 & 74.1 & 81.1 & 18.9 \\
P4-1000 & 61.3 & 80.1 & 28.1 & 71.9 \\
P8-900 & 54.1 & - & 100 & - \\
P8-950 & 74.8 & - & 100 & - \\
P8-1000 & 65.5 & 77.9 & 33.1 & 66.9 \\
\hline
\end{tabular}

${ }^{a}$ The average crystal size of $\mathrm{TiO}_{2}$ was determined by the broadening of the XRD peaks using the Scherrer equation.

${ }^{\mathrm{b}}$ The phase content of $\mathrm{TiO}_{2}$ was obtained using the formulae $W_{\mathrm{R}}=1 /[1$ $\left.+0.884\left(A_{\mathrm{A}} / A_{\mathrm{R}}\right)\right]$ and $W_{\mathrm{A}}=1-W_{\mathrm{R}}$, where $W_{\mathrm{A}}$ and $W_{\mathrm{R}}$ are the content of anatase and rutile, respectively, and $A_{\mathrm{A}}$ and $A_{\mathrm{R}}$ represent the diffraction intensity of anatase (101) and rutile (110), respectively.

increases to $28.6 \mathrm{~nm}$ at $650{ }^{\circ} \mathrm{C}$ and at this temperature, rutile initially begins to form. The coexisting rutile in this sample is three times larger than anatase. By comparison, $\mathrm{P} 2$ at 800 ${ }^{\circ} \mathrm{C}$ retains a relatively small particle size $(25.0 \mathrm{~nm})$. Many researchers have demonstrated the inhibiting effect of phosphorous on particle growth $[23,24,29]$. However, after this temperature, the particle size of anatase grows quickly. P2-900 is two times as large as P2-800. The rutile particle size in P2-950 is only slightly larger than that of the coexisting anatase. To our surprise, the crystal size of anatase in P8-950 is $74.8 \mathrm{~nm}$, which is much larger than the reported critical crystal size for the phase transformation $[30,31]$. This is most peculiar since anatase is believed to be a metastable phase that can exist as small size crystals. Here, we propose a possible mechanism of how the phosphorous species affects the phase transformation. In pure $\mathrm{TiO}_{2}$, grain boundaries provide nucleation sites for rutile formation. The phase conversion is accompanied by simultaneous grain coalescence. One rutile particle consists of several anatase particles and thus the rutile particles are much larger than those of anatase. For $\mathrm{P}_{-} \mathrm{TiO}_{2}$, the phosphate groups on the surface serve as a barrier for grain coalescence and thus prohibit this method of transformation. This is similar to that found by Zhang et al. who enhanced the thermal stability of $\mathrm{TiO}_{2}$ by surface modification with $\mathrm{La}_{2} \mathrm{O}_{3}$ [32]. Above $800{ }^{\circ} \mathrm{C}$, the $\mathrm{P}-\mathrm{TiO}_{2}$ particle size grows very quickly because of the condensation of $\mathrm{P}-\mathrm{O}$ leading to a local structure as in titanium phosphate. Li et al. [25] and Korosi et al. [29] found that titanium phosphate formed upon calcining $\mathrm{P}_{-} \mathrm{TiO}_{2}$ at $900{ }^{\circ} \mathrm{C}$. We did not detect the diffraction peaks of this compound in the XRD patterns probably because the P-content in our study was lower than theirs. However, it is reasonable to postulate that the phosphate groups on the surface may condense at such a high temperature to form a local structure such as titanium phosphate. Additionally, the anatase particles become larger and this trend is more obvious at a higher phosphorus content. By further increasing the annealing temperature, a phase transformation takes place within the single particles. Therefore, the rutile particle size is almost the same as its anatase precursor.

\subsection{Photocatalytic activity assessment}

MB is a typical dye commonly found in effluents from the textile industry. The degradation of $\mathrm{MB}$ on titania roughly follows a pseudo-first-order reaction. The kinetic curves are shown in Fig. 2 and the rate constants are shown
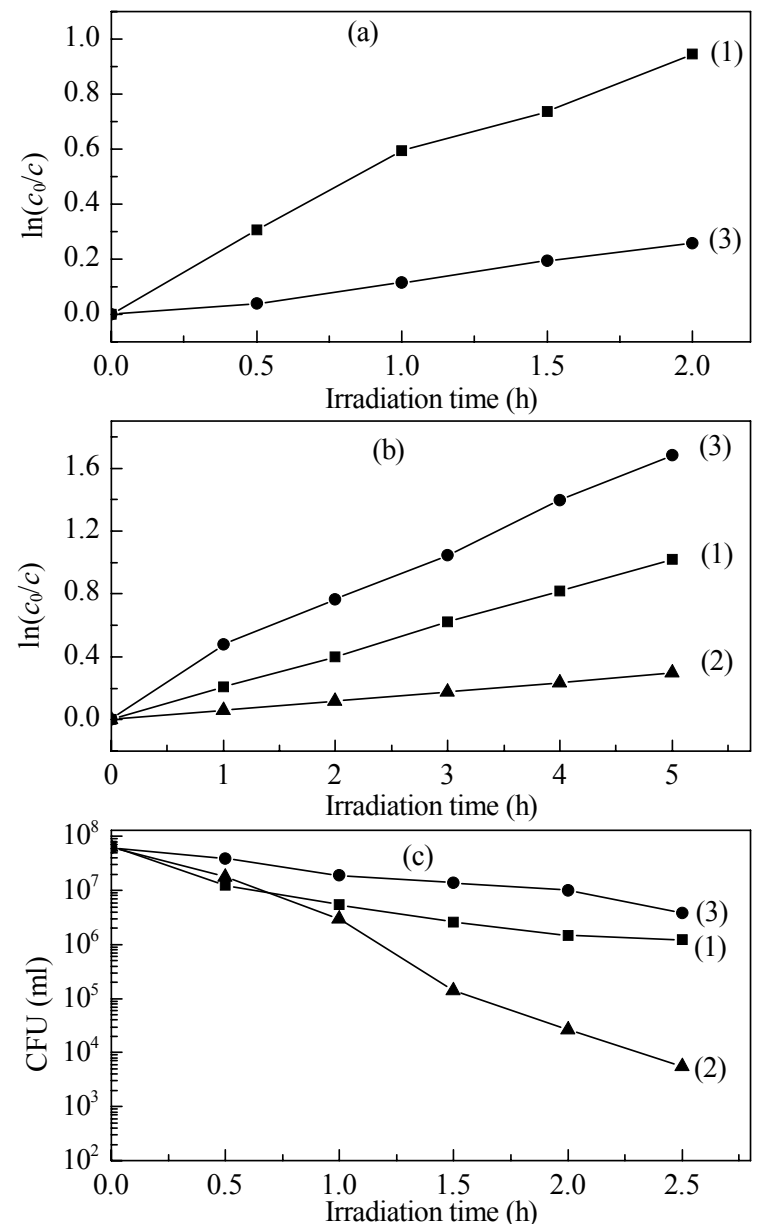

Fig. 2. Kinetic curves of $\mathrm{MB}$ degradation (a), 4CP dechlorination (b), and E. coli inactivation (c) on $\mathrm{P} 25-900$ (1), pure $\mathrm{TiO}_{2}-900$ (2), and P2-900 (3). 
in Table 2. $\mathrm{P} 2$ is more photoactive toward MB degradation than P25 and pure titania. High temperature calcination resulted in a loss of activity for all the samples. The MB removal rate for $\mathrm{P} 2-900$ dropped to $20 \%$ that of $\mathrm{P} 2$ while $\mathrm{P} 25-900$ only had a removal rate $10 \%$ that of $\mathrm{P} 25$. The kinetic curve for pure $\mathrm{TiO}_{2}-900$ is not included in Fig. 2 since MB degradation was negligible for this catalyst and it does not fit a first-order equation.

Table 2 Comparison of MB degradation, 4CP dechlorination and $E$. coli inactivation rate constants on pure $\mathrm{TiO}_{2}, \mathrm{P}-\mathrm{TiO}_{2}$ and $\mathrm{P} 25$ before and after calcination together with the BET surface area of these samples.

\begin{tabular}{lcccc}
\hline Sample & $\begin{array}{c}\text { BET surface } \\
\text { area }\left(\mathrm{m}^{2} / \mathrm{g}\right)\end{array}$ & $k_{\mathrm{MB}} / \mathrm{h}^{-1}$ & $k_{4 \mathrm{CP}} / \mathrm{h}^{-1}$ & $\begin{array}{c}\text { E. coli inactivation } \\
\text { rate }\left(\mathrm{h}^{-1}\right)\end{array}$ \\
\hline $\mathrm{TiO}_{2}$ & 59 & 0.612 & 0.339 & 1.33 \\
$\mathrm{P} 2$ & 104 & 2.49 & 0.423 & 1.81 \\
$\mathrm{P} 25$ & 55 & 1.33 & 0.157 & 5.13 \\
$\mathrm{TiO}_{2}-800$ & 13 & 0.33 & 0.282 & 1.17 \\
$\mathrm{P}_{2}-800$ & 40 & 1.86 & 0.384 & 2.26 \\
$\mathrm{P} 25-800$ & 12 & 0.52 & 0.112 & 1.70 \\
$\mathrm{TiO}_{2}-900$ & 1 & - & 0.204 & 0.49 \\
$\mathrm{P}_{2}-900$ & 15 & 0.47 & 0.327 & 1.63 \\
$\mathrm{P}^{25-900}$ & 1 & 0.13 & 0.060 & 0.69 \\
\hline
\end{tabular}

4CP is widely used as an intermediate in the synthesis of pesticides and insecticides. For 4CP degradation, P2 and the pure sample show similar activity while P25 is not very efficient. The calcined sample P2-900 removed $81 \%$ of the $4 \mathrm{CP}$, which is more than that of pure $\mathrm{TiO}_{2}-900$ and $\mathrm{P} 25-900$ as these gave $64 \%$ and $26 \% 4 \mathrm{CP}$ degradation respectively within the same irradiation time.

Figure 2(c) compares the E. coli inactivation efficiency of these samples. For all the samples, the logarithm of the cell concentration decays linearly as the irradiation time increases and the slope of these curves are shown in Table 2. The rate of cell disinfection on P25 was quite fast and almost all the cells were killed within $60 \mathrm{~min}$. The reason may be that P25 powder is very fine and well-dispersed in the suspension. However, the advantage of phosphorousmodified titania was obvious after calcination. The inactivation ability of P2 did not change much after calcination at $900{ }^{\circ} \mathrm{C}$, and it reduced the $E$. coli concentration from $1 \times 10^{8}$ to $1 \times 10^{3} \mathrm{CFU} / \mathrm{ml}$ while the calcined P25 and pure $\mathrm{TiO}_{2}$ showed limited activity.

In summary, by the phosphorous modification of a $\mathrm{TiO}_{2}$ photocatalyst the rate constants of the three abovementioned reactions increase by factors of $4.1,1.25$ and 1.36, respectively. For the $900{ }^{\circ} \mathrm{C}$-calcined series these values are even higher since the unfavorable effect of annealing on $\mathrm{P}-\mathrm{TiO}_{2}$ is not as obvious as it is on pure $\mathrm{TiO}_{2}$.

\section{4 $-O H$ detection by the TAPL probing technique}

The TAPL technique is widely used for the detection of hydroxyl radicals. As shown in Fig. 3, the PL intensity of 2-hydroxyl-terephthalic acid increases linearly with irradiation time indicating the formation of active $\bullet \mathrm{OH}$. The ability of $\mathrm{P} 2$ to generate $\cdot \mathrm{OH}$ radicals is about $33 \%$ higher than that of pure $\mathrm{TiO}_{2}$ within the same time. In previous work, we measured the density of surface hydroxyl groups [28]. The number of hydroxyl groups for P2 was found to be $7.2 \times 10^{20} / \mathrm{g}$, which is $24 \%$ higher than that of pure $\mathrm{TiO}_{2}$ $\left(5.8 \times 10^{20} / \mathrm{g}\right)$. This might account for the greater ability of $\mathrm{P} 2$ to produce $\cdot \mathrm{OH}$ under illumination.

After annealing pure $\mathrm{TiO}_{2}$ and $\mathrm{P} 2$ at $800{ }^{\circ} \mathrm{C}$, we found a dramatic decrease in the PL intensity for both samples, which is more obvious for pure $\mathrm{TiO}_{2}$. As shown in Fig. 4(a), the PL intensity of P2-800 is 2.7 times higher than that of pure $\mathrm{TiO}_{2}-800$. The $\bullet \mathrm{OH}$ is believed to be the dominant oxidant in these photocatalytic reactions, and this is the reason for the better activity of calcined-P2 during the elimination of pollutants. Phosphorous modification helps to keep $\mathrm{TiO}_{2}$ in anatase phase, which contains a more active surface structure. The surface area of P2-800 is also much

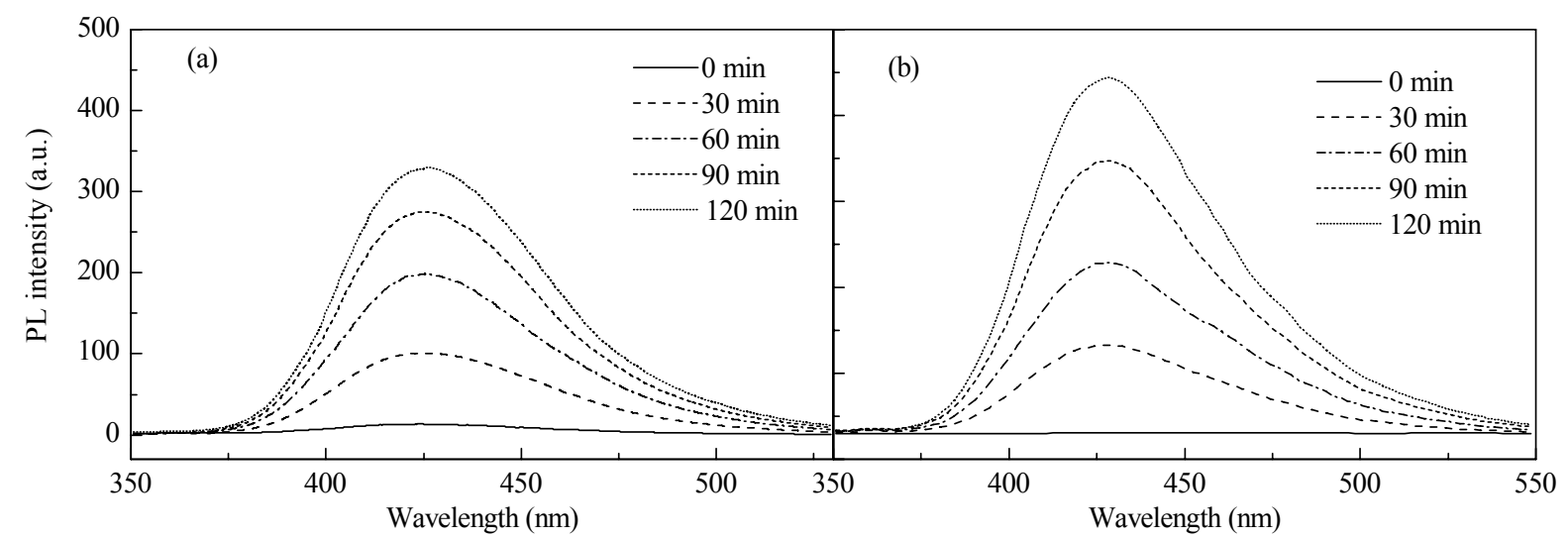

Fig. 3. $\cdot \mathrm{OH}$-trapping PL spectra of pure $\mathrm{TiO}_{2}$ (a) and $\mathrm{P} 2$ (b) suspension in the presence of $3 \mathrm{mmol} / \mathrm{L}$ terephthalic acid. 


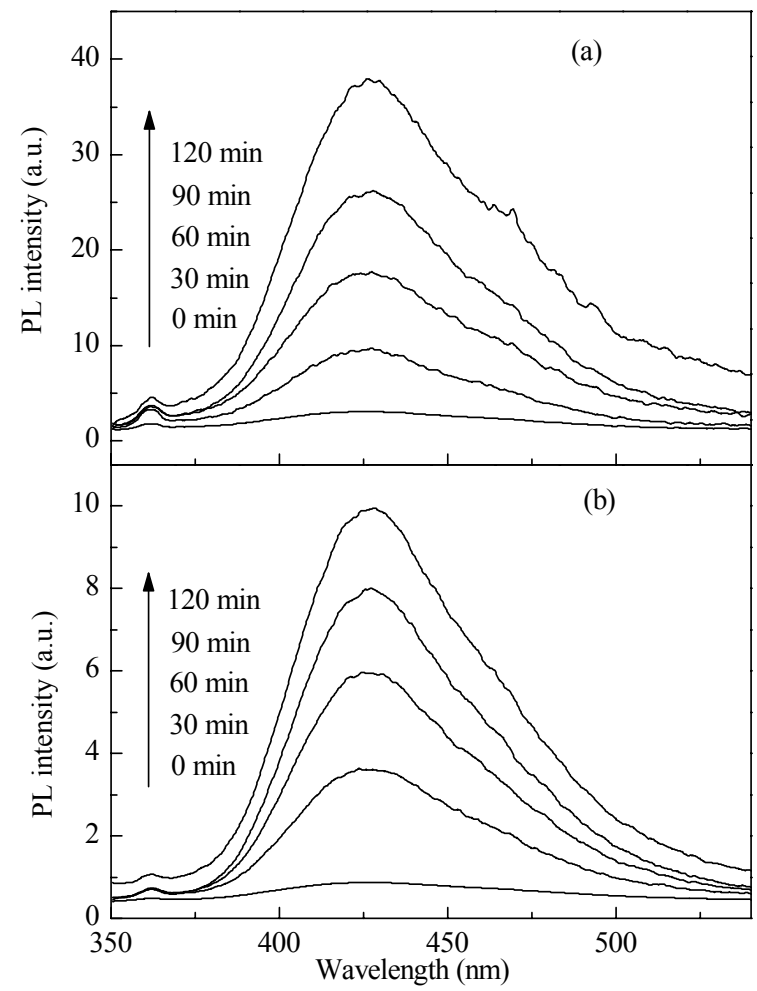

Fig. 4. $\cdot O H$-trapping $\mathrm{PL}$ spectra of pure $\mathrm{TiO}_{2}-900$ (a) and the $\mathrm{P} 2-900$ (b) suspension in the presence of $3 \mathrm{mmol} / \mathrm{L}$ terephthalic acid.

larger than that of $\mathrm{TiO}_{2}-800$ and this facilitates the production of $\cdot \mathrm{OH}$ radicals and in turn this affects the degradation of organic pollutants

\subsection{Possible reaction process}

The mechanistic pathway of MB degradation by $\mathrm{P}_{-} \mathrm{TiO}_{2}$ was determined by investigating the influence of different scavengers on the degradation rate. As shown in Fig. 5, the degradation rate decreased to some extent because of the addition of $100 \mathrm{mmol} / \mathrm{L} \mathrm{NaF}$ but it still remained high $(28.0 / \mathrm{min})$. Fluoride strongly adsorbs onto the surface of $\mathrm{TiO}_{2}$ catalysts. Therefore, the surface-bound or adsorbed - $\mathrm{OH}$ radicals $\left(\cdot \mathrm{OH}_{\mathrm{ads}}\right)$ and the substrate dye molecules on the surface of $\mathrm{TiO}_{2}$ were mostly replaced by $\mathrm{F}^{-}$[33]. We found that the percentage of $\mathrm{MB}$ adsorption on $\mathrm{P}_{-} \mathrm{TiO}_{2}$ decreased from $28.5 \%$ to $7.9 \%$ after the addition of $\mathrm{F}^{-}$. This indicates that the adsorption of substrate molecules plays an important role in $\mathrm{MB}$ degradation but it only accounts for a part of the high efficiency of $\mathrm{P}-\mathrm{TiO}_{2}$.

$\mathrm{KI}$ is known to be a scavenger that reacts with valence band holes [2,34]. The photocatalytic rate was hardly affected by the addition of $20 \mathrm{mmol} / \mathrm{L} \mathrm{KI}$ indicating that $\mathrm{h}^{+}$ are not the active oxidative species involved in this photodegradation system. To determine the role of $\bullet \mathrm{OH}$ in the bulk solution a photocatalytic reaction was carried out in

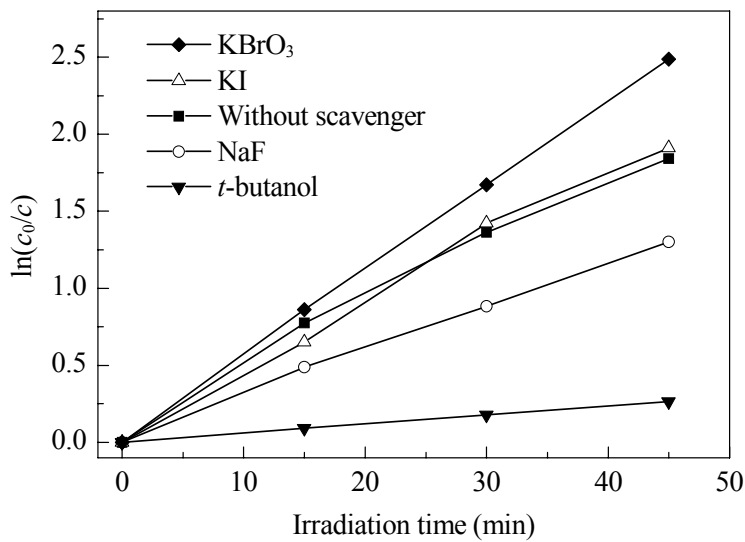

Fig. 5. Kinetic curves of MB degradation on P2.

the presence of $4 \times 10^{-3} \mathrm{~mol} / \mathrm{L} t$-butanol. In this case, MB degradation was almost completely inhibited, which reveals the critical role of bulk $\bullet \mathrm{OH}$. When the reaction was carried out in a trace amount of $\mathrm{KBrO}_{3}$ the degradation rate showed an obvious increase. $\mathrm{KBrO}_{3}$ is a stronger electron acceptor than $\mathrm{O}_{2}$ and prevents electron-hole recombination by trapping electrons [35].

From the above analysis, we obtained an outline of the photocatalytic behavior of $\mathrm{P}-\mathrm{TiO}_{2}$. Both pure $\mathrm{TiO}_{2}$ and $\mathrm{P}-\mathrm{TiO}_{2}$ are well-crystalline after the hydrothermal process. UV-Vis reflection spectra of the two samples do not indicate much difference indicating that they have the same band structure. Therefore, the difference in photocatalytic activity is due to their surface property. Most of the phosphorous species exist as phosphate on the surface of the $\mathrm{TiO}_{2}$ nanoparticles. The phosphate ions replace some of the surface hydroxyl groups and, therefore, the hydroxyl group density per unit area decreases. However, this undesirable outcome is compensated for by an increase in the surface area. Finally, as a result of these two opposite effects, the number of hydroxyl groups per gram for P2 increases by $33 \%$ compared with pure $\mathrm{TiO}_{2}$. The increase in -OH-generating ability for P2 by $24 \%$ corresponds well with this data. The MB degradation performance in the presence of scavengers demonstrates that $\bullet \mathrm{OH}$ is the main oxidative species involved in the photocatalytic reaction. Three reactions were conducted to study the photoactivity of $\mathrm{P}_{-} \mathrm{TiO}_{2}$. Phosphorous modification has an optimizing effect in all the reactions but to a different extent. MB is strongly absorbed on the surface of $\mathrm{P}^{-\mathrm{TiO}_{2}}$. The MB degradation rate constants of $\mathrm{P} 2$ increases about four times compared with that of pure $\mathrm{TiO}_{2}$. The absorption of $4 \mathrm{CP}$ and E. coli on both kinds of $\mathrm{TiO}_{2}$ are almost the same. Therefore, the increase in 4CP degradation and E. coli inactivation is boosted by $25 \%$ and $36 \%$, respectively.

By phosphorous modification the anatase-rutile conversion is greatly retarded. Additionally, the phase 
transformation processes in $\mathrm{P}-\mathrm{TiO}_{2}$ and pure $\mathrm{TiO}_{2}$ are different. The transformation of anatase in $\mathrm{P}_{-} \mathrm{TiO}_{2}$ occurs after the sample has been heavily sintered while a phase conversion of pure $\mathrm{TiO}_{2}$ takes place when the particles are less than $30 \mathrm{~nm}$. This interesting phenomenon is interpreted as a function of the phosphate groups on the surface of $\mathrm{TiO}_{2}$. When the calcination temperature is lower than 800 ${ }^{\circ} \mathrm{C}$ phosphate exists as a barrier on the surface and this inhibits grain coalescence. According to literature, rutile is initially formed at these grain border sites. The barrier effect of phosphate thus hinders the nucleation of rutile at these sites. By increasing the calcination temperature to $900{ }^{\circ} \mathrm{C}$, condensation occurs between the $\mathrm{P}-\mathrm{O}$ bonds and this leads to ultra large anatase nanoparticles. Since the anatase phase is retained, $\mathrm{P}-\mathrm{TiO}_{2}$ exhibits superior activity compared with pure $\mathrm{TiO}_{2}$ and $\mathrm{P} 25$ after calcination at the same temperature.

\section{Conclusions}

This study reveals that phosphorous-modified $\mathrm{TiO}_{2}$ is very effective for the degradation of water pollutants such as $\mathrm{MB}, 4 \mathrm{CP}$, and $E$. coli. The main active species in the $\mathrm{P}-\mathrm{TiO}_{2}$ system that attacks the substrate molecule is free - $\mathrm{OH}$ radicals. We also demonstrate that $\mathrm{P}-\mathrm{TiO}_{2}$ has a high capacity for generating $\cdot \mathrm{OH}$ radicals under illumination. This excellent feature is probably due to its large surface area and abundant surface hydroxyl groups. Phosphorous modification also enhances the thermal stability of anatase. The phase transformation from anatase to rutile does not occur until $950^{\circ} \mathrm{C}$. Since $\mathrm{P}-\mathrm{TiO}_{2}$ retains its anatase phase at $900{ }^{\circ} \mathrm{C}$ it naturally shows promising performance for the degradation of organic pollutants and the inactivation of $E$. coli. The excellent thermal stability of $\mathrm{P}_{-} \mathrm{TiO}_{2}$ is promising for its application in antibacterial ceramics.

\section{References}

1 Legrini O, Oliveros E, Brauna A M. Chem Rev, 1993, 93 : 671

2 Hoffmann M R, Martin S T, Choi W, Bahnemann D W. Chem Rev, 1995, 95: 69

3 Andreozzi A R, Caprio V, Insola A, Marotta R. Catal Today, 1999, 53: 51

4 Linsebigler A L, Lu G, Yates J T. Chem Rev, 1995, 95: 735

5 Lawless D, Serpone N, Meisel D. J Phys Chem, 1991, 95: 5166

6 Cho M, Chung H, Choi W, Yoon J. Water Res, 2004, 38: 1069

7 Gandhe A R, Naik S P, Fernandes J B. Microporous Mesoporous Mater, 2005, 87: 103

8 Kumar K N P, Keizer K, Burggraaf A J, Okubo T, Nagamoto
H, Morooka S. Nature, 1992, 358: 48

9 Shannon R D, Pask J A. J Am Ceram Soc, 1965, 48: 391

10 Gouma P I, Dutta P K, Mills M J. Nano Mat, 1999, 11: 1231

11 Machida M, Norimoto K, Kimura T. J Am Ceram Soc, 2005, 88: 95

12 Hirano M, Ota K, Iwata H. Chem Mater, 2004, 16: 3725

13 Periyat P, Pillai S C, Mccormack D E, Colreavy J, Hinder S J. J Phys Chem C, 2008, 112: 7644

14 Choi H, Kim Y J, Varma R S, Dionysiou D D. Chem Mater, 2006, 18: 5377

15 Colon G, Hidalgo M C, Munuera G, Ferino I, Cutrufello M G, Navio J A. Appl Catal B, 2006, 63: 45

16 卢晗锋, 周瑛, 徐柏庆, 陈银飞, 刘化章. 分子催化 $(\mathrm{Lu} \mathrm{H}$ F, Zhou Y, Xu B Q, Chen Y F, Liu H Zh. J Mol Catal(China)), 2008, 22: 54

17 Li H X, Zhang X Y, Huo Y N, Zhu J. Environ Sci Tech, 2007, 41: 4410

18 张敬畅, 高玲玲, 曹维良. 无机化学学报 (Zhang J Ch, Gao L L, Cao W L. Chin J Inor Chem), 2003, 19: 934

19 陈艳敏, 钟晶, 陈锋, 张金龙. 催化学报 (Chen Y M, Zhong J, Chen F, Zhang J L. Chin J Catal), 2010, 31: 120

20 魏风玉, 桑蕾. 催化学报 (Wei F Y, Sang L, Chin J Catal), 2009, 30: 335

21 郑华荣, 崔言娟, 张金水, 丁正新, 王心晨. 催化学报 (Zheng H R, Cui Y J, Zhang J S, Ding Zh X, Wang X Ch. Chin J Catal), 2011, 32: 100

22 Zhao D, Chen C C, Wang Y F, Ji H W, Ma W H, Zang L, Zhao J C. J Phys Chem C, 2008, 112: 5993

23 Yu J C, Zhang L Z, Zheng Z, Zhao J C. Chem Mater, 2003, 15: 2280

24 Korosi L, Papp S, Bertoti I, Dekany I. Chem Mater, 2007, 19: 4811

25 Li F F, Jiang Y S, Xia M S, Sun M M, Xue B, Liu D R, Zhang X G. J Phys Chem C, 2009, 113: 18134

26 Zheng R Y, Lin L, Xie J L, Zhu Y X, Xie Y C. J Phys Chem C, 2008, 112: 15502

27 Yang H G, Liu G, Qiao S Z, Sun C H, Jin Y G, Smith S C, Zou J, Cheng H M, Lu G Q. J Am Chem Soc, 2009, 131: 4078

28 Jin C, Zheng R Y, Guo Y, Xie J L, Zhu Y X, Xie Y C. J Mol Catal A, 2009, 313: 44

29 Korosi L, Oszko A, Galbacs G, Richardt A, Zollmer V, Dekany I. Appl Catal B, 2007, 77: 175

30 Zhang H Z, Banfield J F. J Mater Chem, 1998, 8: 2073

31 Reidy D J, Holmes J D, Morris M A. J Eur Ceram Soc, 2006, 26: 1527

32 Zhang J, Li M J, Feng Z C, Chen J, Li C. J Phys Chem B, 2005, 110: 927

33 Mendive C B, Bahnemann D W, Blesa M A. Catal Today, 2005, 101: 237

34 Joo J, Kwon S G, Yu T, Cho M, Lee J, Yoon J, Hyeon T. J Phys Chem B, 2005, 109: 15297

35 Irmak S, Kusvuran E, Erbatur O. Appl Catal B, 2004, 54: 85 